\title{
THE EFFECTS OF INCOME ON CHILDREN'S HEALTH: EVIDENCE FROM SUPPLEMENTAL SECURITY INCOME ELIGIBILITY UNDER NEW YORK STATE MEDICAID
}

\author{
Hansoo Ko \\ Renata E. Howland \\ Sherry A. Glied \\ Working Paper 26639 \\ http://www.nber.org/papers/w26639
NATIONAL BUREAU OF ECONOMIC RESEARCH
1050 Massachusetts Avenue
Cambridge, MA 02138
January 2020

This research was funded by grant 73216 from the Robert Wood Johnson Foundation's Policies for Action program. The views and opinions expressed in this paper are those of the authors and do not necessarily reflect the official policy or position of the New York State Department of Health, and also do not necessarily reflect the views of the National Bureau of Economic Research.

NBER working papers are circulated for discussion and comment purposes. They have not been peer-reviewed or been subject to the review by the NBER Board of Directors that accompanies official NBER publications.

(C) 2020 by Hansoo Ko, Renata E. Howland, and Sherry A. Glied. All rights reserved. Short sections of text, not to exceed two paragraphs, may be quoted without explicit permission provided that full credit, including $\odot$ notice, is given to the source. 
The Effects of Income on Children's Health: Evidence from Supplemental Security Income Eligibility under New York State Medicaid

Hansoo Ko, Renata E. Howland, and Sherry A. Glied

NBER Working Paper No. 26639

January 2020

JEL No. H55,I10,I38

\section{ABSTRACT}

There is a well-established association between income and child health. We examine the Supplemental Security Income (SSI) program, which provides cash assistance to low-income children with disabilities, to assess how this relationship arises. We use a large database of Medicaid administrative records to estimate the causal effects of SSI receipt on children's health, using a regression discontinuity design that exploits the rule that low-income children born below a birthweight threshold are automatically eligible for SSI. We find that children whose birthweights fall below the threshold are significantly more likely to be awarded SSI. Over the first 8 years of their lives, children with birthweights just below the threshold incur Medicaid expenditures $30 \%$ lower than do those born just above the threshold. They are less likely to be admitted to hospital, have shorter hospital stays when admitted, and use fewer specialist services. Eligible children experience reduced rates of diagnosis across a range of conditions, with significantly lower rates of both acute (infection, injury) and chronic (malnutrition, developmental delay) conditions in early life. SSI receipt delays the incidence of new chronic conditions by 1.7 months and reduces the number of new chronic conditions recorded through age 3 by $15 \%$. Past health shocks significantly increase current healthcare utilization, but an interaction term between the SSI eligibility and past health shocks is not statistically significant, a pattern that suggests that increased income derived from SSI reduces the incidence of early health shocks but does not change how families respond to these shocks. Children receiving SSI are more likely to live in higher income neighborhoods mainly because their families are less likely to move out of better neighborhoods. However, we do not find evidence that children's receipt of SSI affects their mother's health or fertility. Reductions in Medicaid spending associated with SSI eligibility offset increased cash transfer payments by a ratio of 3.3:1.

Hansoo Ko

Robert F. Wagner Graduate School of Public Service

New York University 295

Lafayette St., 2nd floor

New York, New 10012

hansooko@nyu.edu

Renata E. Howland

Robert F. Wagner Graduate School

of Public Service

New York University

295 Lafayette St., 2nd floor

New York, New 10012

reh6@nyu.edu
Sherry A. Glied

Robert F. Wagner Graduate School

of Public Service

New York University

295 Lafayette Street, 2nd Floor

New York, NY 10012

and NBER

sherry.glied@nyu.edu 


\section{Introduction}

In 2018, 16.2 percent of American children (approximately 12 million) lived in families with incomes below the federal poverty threshold (U.S. Census Bureau, 2019). Cash transfers, as well as other in-kind transfers, provide benefits to help expand families' budgets and allow low-income parents to optimize investment in their children (Almond, Currie, 2011). A growing body of research shows that such investments in early life have significant long-term impacts, including improved educational attainment and earnings (Hoynes, Schanzenbach, 2018). Cash transfers have also been found to improve long-term health outcomes including longevity (Aizer et al., 2016), ${ }^{1}$ nutrition (Milligan, Stabile, 2011; Aizer et al., 2016), mental health (Milligan, Stabile, 2011; Akee et al., 2018), and maternal mental health (Milligan, Stabile, 2011). But the process through which income improves child health is not well understood.

In the United States, Supplemental Security Income (SSI) provides means-tested cash assistance to the elderly and to individuals with disabilities, including children. SSI is administered by the Social Security Administration (SSA), which is responsible for screening applicants based on income, assets, citizenship, and eligibility categories (age, vision, and disability) and making SSI awards. Beginning in 1993, low birthweight became a presumptive disability category ("premature children”) for SSI ${ }^{2}$. This allowed families of premature babies to be awarded cash benefits for up to six months while their applications were under review for eligibility determination. Later, in 2015, low birthweight became its own medical listing in 2015 (Guldi et al., 2018). Eligibility for benefits based on low birthweight is based on weight relative to gestational age, which SSA gathers from birth certificates. After 32 weeks of gestational age, the SSI eligibility threshold gradually

\footnotetext{
${ }^{1}$ Conversely, reduced social welfare benefits resulted from the 1996 welfare reform was associated with an increase in infant mortality (Leonard, Mas, 2008).

${ }^{2}$ This change followed the 1991 decision of SSA that low birthweight is a condition functionally equivalent to meeting conventional medical listings.
} 
increases from 1,200 grams: to 1,250 grams at 32 weeks, 1,325 grams at 33 weeks, 1,500 grams at 34 weeks, 1,700 grams at 35 weeks, 1,875 grams at 36 weeks, and 2,000 grams at 37-40 weeks. For children who gain eligibility due to low birthweight, SSA typically conducts Continuing Disability Reviews (CDR) within 1 year of birth or later (Hemmeter, Bailey, 2015). ${ }^{3}$ If an otherwise eligible child is found not to have any significant developmental delays, SSI benefits may end. In 2018, of the 17,346 children who qualified for SSI benefits based on low birthweight, only 49.8\% were deemed eligible for continuing benefits (SSA, 2019; Guldi et al., 2018).

SSI support can provide a substantial source of income for families (Guldi et al., 2018). Duggan and Kearney (2007), using the Survey of Income and Program Participation (SIPP) data and following families of disabled children before and after SSI participation, estimate that child SSI enrollment reduces the likelihood that children live in poverty by 11 percentage points. Their household-level fixed effects estimation finds that an additional \$100 of child SSI benefits increases household income by $\$ 72$ (Kubik, 1999). ${ }^{4}$

Cash transfers in early life may be particularly valuable to children at high risk of adverse health outcomes, such as those born at low birthweight. Prior research documents that low birthweight has persistent effects on later life outcomes (Black et al., 2007). Cash benefits for low birthweight children could improve well-being by offsetting extra disability-related expenditures or by replacing earnings of parents who have to reduce their work hours to take care of a disabled child (Daly, Burkhauser, 2003). While one study (Currie, Hyson, 1999) found that family income does

\footnotetext{
${ }^{3}$ According to Hemmeter and Bailey (2015), however, more than 90\% of low birthweight SSI recipients received their first CDR decision at age 1-3 during 1998-2008.

${ }^{4}$ It reflects the program rule that a child is not able to receive benefits from both SSI and other social welfare program such as Temporary Assistance for Needy Families (TANF). Because of SSI's more generous benefits, there have been more children in households with SSI income than children living in households with TANF income (Duggan, Kearney, 2007).
} 
not fully mitigate the negative effects of low birthweight, the evidence directly exploring the relationship between SSI and child outcomes is limited.

To our knowledge, only one study on the effects of child SSI receipt on outcomes exists (Guldi et al., 2018). Using a nationally representative longitudinal data set and exploiting the 1,200-gram birthweight cutoff for SSI eligibility, Guldi et al. (2018) find that eligibility increases the probability that families of low birthweight children benefit from SSI for the first two years of their life by 25-30 percentage points. The authors estimate that these SSI benefits for low birthweight infants increase child motor skill development scores (Bayley Mental Motor scale) by 0.4-0.7 of standard deviation and reduce maternal labor market participation on the intensive margin (54.6\% of the mean of mother's weekly hours worked), without affecting child mortality. Their dataset, however, has several limitations. The sample size is small (N=150-650 depending on specification) and SSI participation is measured at the household level, not the child level. They also do not have direct measures of health service utilization.

Our study builds on this work by using Medicaid administrative data from New York State to estimate the causal effects of SSI on a comprehensive range of child health measures over 8 years of follow-up. We use a regression discontinuity design and exploit variation in eligibility for SSI based on birthweight. We find that being born below the low birthweight cutoff increases the probability of SSI enrollment before age one by 93\%. In early childhood (before age 6), SSI recipients are significantly less likely to be diagnosed with both acute (infection, injury) and chronic (malnutrition, developmental delay) conditions, and have a decreased probability of hospital admission.

The effects of SSI eligibility on health span a wide range of outcomes, although only a minority are statistically significant. Looking across outcomes, we find that children birthweight-eligible 
for SSI incur 30\% lower Medicaid costs by age 8 than children born just above the threshold. Reductions in Medicaid costs occur across the distribution of spending, at and above the median, with the greatest impacts at the top of the Medicaid cost distribution.

In an earlier descriptive analysis, Currie and Stabile (2003) examine whether socioeconomic gradients in health occur because of differences in the rate of incidence of health shocks or because of differences in the response to these shocks. Following their approach, we find that birthweight eligibility for SSI delays the incidence of new chronic conditions by 1.7 months and reduces the number of new chronic conditions diagnosed by age 3 by $15 \%$. We also find that past health shocks significantly increase current healthcare utilization, but, like the earlier literature, we find that an interaction term between the SSI eligibility and past health shocks is not statistically significant. This pattern implies that the increased income received through SSI reduces the probability that a child is subject to health shocks in early life, but does not change how families respond to these shocks (Case et al., 2002; Currie, Stabile, 2003).

We find that children birthweight-eligible for SSI also live in higher income neighborhoods by age 8 , mainly because their families are less likely to move out of such neighborhoods than are families whose infants were born above the threshold. Unlike a prior cash transfer study (Milligan, Stabile, 2011), we do not find evidence of protective effects of increased unearned income extend to maternal health outcomes.

Reductions in Medicaid spending associated with SSI eligibility are substantial; while our study population only accounts for $0.7 \%$ of the entire 2006-2010 Medicaid birth cohort, their total Medicaid costs through age 8 are about $4 \%$ of the total costs incurred by the whole cohort. Reductions in Medicaid spending associated with SSI eligibility offset increased cash transfer payments by a ratio of 3.3:1. 


\section{Method}

Our study uses New York State Medicaid claims data. We restrict the sample to include lowincome children born in the state of New York between 2006 and $2010^{5}$ whose birthweights fall between 900 grams and 1,500 grams. Our primary study sample is restricted to include only those continuously enrolled in Medicaid (without any lapse in coverage) from birth until age 8 (we relax this restriction in sensitivity analyses below). ${ }^{6}$ We further restrict our study sample to those born at 32 weeks of gestation or earlier (ICD-9 diagnosis codes: 765.21-765.26), to limit bias due to errors in determination of birthweight eligibility at higher gestational ages (we test this restriction in sensitivity analyses below). Our final sample includes 1,348 low birthweight, preterm births from low-income households in the state of New York.

To examine the impacts of SSI, we exploit the 1,200-gram threshold in a regression discontinuity design by comparing children whose birthweight fall just below the threshold (and are more likely to benefit from SSI) to children above the threshold, using the following parametric linear regression model:

(1) $Y_{i}=\alpha+\beta_{1} D_{i}+\beta_{2} B W_{i}+\beta_{3} D_{i} B W_{i}+X_{i}+\varepsilon_{i}$

where $B W$ is birthweight in grams (centered at 1,200 grams) of child $i, D$ is an indicator that equals one if birthweight is smaller than 1,200 grams, and $X_{i}$ is a vector of demographic factors including race/ethnicity (non-Hispanic White, non-Hispanic black, Hispanic, non-Hispanic other

\footnotetext{
5 The 2006 data are the earliest and the 2018 data are the latest we are able to use. Note that the 2006-2010 birth cohort was not affected by the 1996 welfare reform which toughened the disability standard for SSI participation (Kubik, 1999).

${ }^{6}$ Among all the 3,690 preterm babies born in 2006-2010 whose birthweights fell between 900 and 1,500 grams, $35.2 \%$ were continuously enrolled in Medicaid for the first eight years of life.
} 
race/ethnicity), gender, and birth month and birth year fixed effects. ${ }^{7}$ We also control for trend in birthweight by interacting the treatment group indicator and the birthweight measure. In addition, our main specification includes full interactions between birth year dummies, gender, and race/ethnicity.

Outcome measures $Y_{i}$ include medical conditions children experienced during the study period identified through diagnosis codes in the Medicaid encounter data. Following previous studies (Case et al., 2002; Clark et al., 2019), we include a set of common conditions in childhood as outcome measures by grouping conditions using the Clinical Classifications Software (CCS) system, leaving aside rare conditions for this study population (for instance, hypertension, diabetes mellitus, and renal failure). In addition, we focus on single conditions such as the incidence of inadequate nutrition (malnutrition), maltreatment (injury), and infection, which are expected to be affected by an improved household environment (Lee, Mackey-Bilaver, 2007; Schnitzer et al., 2011; Phil, Basso, 2019). We also measure overall healthcare utilization as total Medicaid costs, hospitalization utilization, and specialist visits.

To test if SSI benefits affected maternal health outcomes, in the way the Canada Child Tax Benefit program improved maternal mental health (Milligan, Stabile, 2011), we estimate the impacts of increased unearned income on maternal outcomes including mental health, fertility, and healthcare utilization by applying an algorithm linking mothers to the 2006-2010 cohort through administrative case identification numbers and birth dates (Knox et al., 2019). Using this method, we were able to identify $94 \%$ of mothers.

\footnotetext{
${ }^{7}$ In addition to the general purpose of controlling for socioeconomic health shocks common to each cohort, including the birth year and birth month fixed effects is beneficial given the fluctuation in the cessation rate after SSA's CDR (which presumably reflect administrative reasons) (Hemetter, Bailey, 2015).
} 
We used information on residential address records to explore the effect of SSI on residential mobility and neighborhood characteristics. We characterize mobility as the probability of moving (zip codes had ever changed during the study period), number of moves (total number of changes of zip codes), and logged distance moved in miles (great-circle distance between centroids of zip code tabulation arears). We also explore whether children moved into or moved out of New York City.

We match each child's residential address to the American Community Survey (ACS) five-year estimates of neighborhood socioeconomic status to capture the changes in neighborhood environment each child experienced. We use census tracts as a proxy for neighborhoods and utilize the 2009 ACS five-year estimates (covering 2005-2009) to describe neighborhood characteristics at birth and the 2017 ACS five-year estimates (covering 2013-2017) to measure the characteristics of the neighborhood where children lived at age 8. We calculate net changes in poverty level, net changes in educational attainment (the share of adults who graduated high school, and the share of adults who earned bachelor's degree), and changes in median household income (expressed as CPI-adjusted \$2009).

We use Calonico et al.'s (2017) bandwidth selection method, which yields 250-300 gram as a bandwidth and use a 300-gram bandwidth for our main specification to maximize sample size (we also estimate the impacts of SSI on our main outcome measures with a 250-gram bandwidth as a sensitivity check). We test manipulation of birthweight around the threshold by using Cattaneo et al.’s (2015) manipulation test with local polynomial density estimation and find no evidence of manipulation around the 1,200-gram cutoff ( $\mathrm{p}=0.849)$.

Our main specifications report intent-to-treat (ITT) estimates of the impacts of SSI. We also report treatment on the treated (TOT) effect estimates by specifying a fuzzy regression discontinuity 
design given that many SSI-eligible children below the threshold did not receive the benefits and some children above the threshold did receive SSI benefits. We estimate TOT effects in a twostage least squares framework where SSI spells are regressed using the 1,200-gram threshold in the first stage. Note that we primarily rely on SSI spells instead of a binary indicator (ever being on SSI) to recover the impacts of additional benefit amounts.

As ITT estimates are a weighted average of local average effects of compliers and local average effects of never takers, differences between ITT and local average treatment effect (LATE), if any, may be worth further exploration. Following Abadie’s (2003) kappa-weighted means theorem $\left(E\left[x \mid D_{1}>D_{0}\right]=\frac{E\left[D_{i} \mid Z_{i}=1, x=1\right]-E\left[D_{i} \mid Z_{i}=0, x=1\right]}{E\left[D_{i} \mid Z_{i}=1\right]-E\left[D_{i} \mid Z_{i}=0\right]}\right)$, we compute the relative probability that each group (complier/always taker/never taker) has certain observable characteristics such as gender, race/ethnicity, residency (New York City versus rest of the state), and neighborhood socioeconomic level.

\section{Results}

Table 1 reports summary statistics of our study sample. The first column shows means for the whole sample. The second and third columns report means for the sample whose birthweights fall below the 1,200-gram cutoff (thus eligible for SSI) and fall above the birthweight cutoff. Our study sample is $47 \%$ female, $34 \%$ non-Hispanic White, $22 \%$ non-Hispanic Black, 31\% Hispanic, and 51\% New York City residents. Our identification relies on the assumption that both observable and unobservable factors related to outcome measures are continuous at the 1,200-gram cutoff. As a first check, we test whether differences between the two groups are significant. There are few statistically significant differences between the two groups, except for the share of female and location of residency. 
Consistent with our expectations, SSI enrollment is significantly higher among children born below the threshold. By age 1, 59\% of eligible children (below the cutoff) were enrolled in SSI, compared to $17 \%$ of children above the threshold. Average SSI spells by age 1 are 5.1 months below the cutoff and 1.2 months above the cutoff. Appendix Table 1 further explores the differences in SSI enrollment by age 1 classified by demographics. Results indicate that SSI enrollment, both on the intensive and extensive margins, is significantly higher below the 1,200gram cutoff across the all subgroups. Figure 1 plots local linear regression fitted values of cumulative SSI enrollment by age 8 with a 300-gram bandwidth, quadratic function of the running variable, and triangular kernel function. The figure shows that the association of birthweight with SSI enrollment, both in terms of the probability of SSI enrollment and SSI spells, is negative and linear in general, but discontinuous at the 1,200-gram cutoff for the child SSI benefit.

Appendix Table 2 presents first stage regressions of the indicator that birthweight is below 1,200 grams on the months on SSI during the indicated age intervals. Consistent with expectations, the birthweight cutoff is significantly positively associated with SSI spells only in a child's early life. Birthweight below the 1,200-gram cutoff increases SSI spells by around 2 months per year until age three. However, the significance of the effect disappears later in life, indicating that CDR resulted in many cessation cases below the cutoff. Results also show evidence that child SSI enrollment increases in age above the cutoff, suggesting newly-diagnosed physical/mental impairments among children born above the cutoff.

In Appendix Table 3, we further explore SSI enrollment trajectories between the two groups through age eight. We find that children below the cutoff initially enrolled in SSI earlier in life, particularly before their first birthdays. Among all children below the cutoff who ever enrolled in SSI, 79.2\% enrolled in SSI by age 1. By contrast, among those born above the cutoff, $53.7 \%$ 
enrolled in SSI for the first time after age one. Among those enrolled in SSI and born below the cutoff, only 30\% of those children enrolled in SSI for the first time by age 1 remained on SSI continuously until age eight. Lapse in SSI benefit among children below the threshold occurred most frequently at around age 2-4, relative to children on SSI born above the cutoff. Our data do not contain information on the reason for lapse in SSI benefit; however, the pattern we observe is consistent with the findings of Hemmeter and Bailey (2015), who show that a majority of low birthweight child SSI enrollees received their first CDR at age 1-4 and that SSA ended benefits in $33-48 \%$ of cases.

Table 2 presents estimated ITT effects of SSI ( $\beta_{1}$ from equation (1)) on the cumulative prevalence of common conditions. Crossing the 1,200-gram cutoff for SSI eligibility increases SSI spells by $102 \%$ between ages $0-3$ and increases SSI spells by $24 \%$ between ages $3-6$. Results show that the incidence of malnutrition and urinary tract infection prior to age three are significantly lower below the threshold.

We also find that crossing the eligibility cutoff decreases the incidence of developmental delay and the receipt of special education by 10 percentage points between ages 3-6. Results for almost all conditions are negative, though only a few reach statistical significance. In Appendix Table 4, we present a full set of estimated health impact of SSI. We find evidence that SSI reduces the incidence of fever of unknown origin, upper respiratory tract infection, digestive diseases, and burns early in life.

Aggregate Medicaid expenditures, which capture utilization across the full range of conditions, are significantly lower among those birthweight-eligible for SSI. Table 3 reports the ITT effects of SSI on healthcare utilization. SSI reduces Medicaid costs by $27-36 \%$ through age eight. SSI also decreases the probability of hospital utilization (excluding initial stays at birth) by 10.6 
percentage points (14.7\% of the mean) by age 3. Children eligible for SSI also spend fewer total days in hospital, with length of stay $32.6 \%$ lower by age three. ${ }^{8}$ Children eligible for SSI because of low birthweight have a significantly lower probability of being hospitalized for urinary tract diseases and injury. Specialist visits are also substantially lower among those born below the cutoff (-40-63\% of the mean). Coefficients on the probability of hospitalization for infection, nutritional and metabolic diseases, digestive diseases, and diseases of the nervous and sensory organs are negative, though statistically insignificant. These results suggest that SSI reduces the incidence of severe medical conditions requiring costly services in early childhood.

\section{Mechanisms}

Our results indicate that SSI reduces the incidence of both acute (infection and injury) and chronic (malnutrition and developmental delay) conditions in early life, and leads to substantial reductions in Medicaid spending. To further investigate the mechanism through which SSI eligibility affects the health of children, we first explore when a child was initially diagnosed with chronic conditions and how these health shocks affect healthcare utilization later in the child's life.

Currie and Stabile (2003) hypothesize that financial resources may help children avoid adverse health shocks and may help families deal with those health shocks that do occur. In Table 4, we find that children born at birthweights above the cutoff were diagnosed with chronic conditions ${ }^{9}$ 1.7 months earlier, on average, than were children born below the cutoff. We also find that SSI reduces the incidence of new chronic conditions (not diagnosed in the previous periods) through

\footnotetext{
${ }^{8}$ This estimated impact is unconditional on a stay. The impact on stays conditional on any hospitalization is quite similar; SSI reduces length of stay by 14.986 days from birth to age 3 (32.6\% of the mean) and reduces length of stay by 16.482 days until age 8 (35.2\% of the mean).

${ }^{9}$ These include 9 conditions shown in Appendix Table 4 with the chronic nature of medication and follow-ups; malnutrition, anemia, obesity, vision defect, hearing defect, asthma, genitourinary tract diseases, and developmental delay.
} 
age three (the age at which the differential in SSI between birthweight and non-birthweight eligible children is significant (Appendix Table 2)). A fuzzy regression discontinuity estimation (SSI spells by age 3 are instrumented by an indicator for birthweight below the cutoff) in Appendix Table 5 provides similar results; an additional month on SSI delays the arrival of new chronic conditions by 0.3 month and decreases the number of new chronic conditions by $2.4 \%$ of the mean.

Replicating the methods of Case et al. (2002) and Currie and Stabile (2003) in their descriptive analyses, we also estimate a regression of current healthcare utilization on an interaction term between the low birthweight threshold and a chronic condition indicator diagnosed in previous period (Table 5). Results show that the presence of chronic conditions diagnosed by age 3 significantly increase healthcare utilization in future periods, suggesting that past negative health shocks affect the subsequent health of children. ${ }^{10}$ However, an interaction term between the SSI eligibility and past health shocks is small and not significantly different from zero, indicating that the effect of past health shocks on current utilization does not differ by increased household income. Appendix Table 6 reports results from two-stage least squares regression of current healthcare utilization on SSI spells by age 3 (instrumented by an indicator for the low birthweight eligibility) and similarly shows that both additional months on SSI by age 3 and chronic conditions diagnosed by age 3 are associated with current utilization, but that the interaction term is small and not statistically significant. These results suggest that the increased income obtained through SSI does not change how families respond to health shocks, but reduces the probability that a child is subject to health shocks.

\footnotetext{
${ }^{10}$ The low birthweight eligibility for SSI also independently affects utilization measure, though coefficients become less significant compared to our main specification in large part due to collinearity between the low birthweight eligibility and an indicator for diagnosis of chronic condition (shown in Table 4).
} 
We also run a fuzzy regression discontinuity estimation (instrument: indicator whether birthweight is below 1,200 grams) of cumulative Medicaid costs in Appendix Table 7. We present first stage and second stage regression coefficients, where the first stage coefficients are cumulative SSI spells for indicated age intervals. Consistent with the results shown in Appendix Table 2, the association of the low birthweight threshold with SSI take-up gradually decreases in age. TOT effects of SSI on Medicaid costs are statistically significant until age 7, though the marginal effects of SSI benefit significantly decrease as a child ages. This finding corroborates our identification assumption that the Medicaid cost-saving effects of SSI we observe are primarily driven by exogenous variation in exposure to social welfare benefits based on the low birthweight eligibility criterion. Our findings imply that any lasting effects (especially beyond age 3) of SSI are generated by cash benefits transferred in early life.

Table 6 presents ITT effects of SSI on the mobility of families of affected children. We find evidence that SSI does not significantly affect the probability of moving, number of moves, or the probability of moving into/out of New York City by age 8 . However, children below the 1,200gram cutoff experienced significant improvements in neighborhood environments. The change in census tract level median household income between birth and age 8 is about $\$ 8,500$ ( $156 \%$ of the mean) greater for children below the cutoff. Low birthweight SSI eligibility is also marginally significantly associated with an increase in bachelor's degree completion rate at the census tract level. These estimates suggest that neighborhood environment improves for children born below the threshold because they are less likely to move out of better neighborhoods.

We present impacts of SSI on cumulative maternal health outcomes and fertility until children's age 8 in Table 7. We find no evidence of impacts of child SSI receipt on mental health, fertility, 
substance- and alcohol-related disorders. ${ }^{11}$ Child's SSI eligibility is negatively associated with mother's Medicaid costs, the probability of anxiety, pregnancy, and hospitalization utilization, but none of these results are statistically significantly different from zero ${ }^{12}$.

Table 8 reports distributional effects of SSI through age 8. Reductions in Medicaid costs occur across the distribution of spending, at and above the median, with the greatest impacts at the top of the Medicaid cost distribution. SSI is not significantly associated with changes in Medicaid costs below the $25^{\text {th }}$ percentile, but the estimated cost-saving impacts of SSI are $27.5 \%$ at the median, $36.1 \%$ at the $75^{\text {th }}$ percentile, and $53.7 \%$ at the $90^{\text {th }}$ percentile. We also find similar distributional effects for the number of hospitalization and specialist visits. In contrast, results reveal that children eligible for SSI benefit experienced improved neighborhood environment across the whole distribution with similar impact size.

\section{Robustness}

We present results from alternative specifications in Table 9. The second column shows estimation results using a narrower birthweight bandwidth (250 grams). Although standard errors are bigger due to a smaller sample size $(\mathrm{N}=1,122)$, results are qualitatively similar to our main specification. In our main estimates, we restrict the study sample to those born at 32 weeks of gestation or earlier. We compare ITT estimators of the impacts of SSI between the sample restricted to preterm birth $(\mathrm{N}=1,348)$ and the sample without the preterm birth restriction $(\mathrm{N}=1,871)$ in the third column. Estimated impacts from an analysis using the sample without the preterm birth restriction are smaller than our main specification, indicating that measurement error leads to a bias toward zero.

\footnotetext{
${ }^{11}$ In an unreported analysis, we estimate the effect of having a sibling birthweight-eligible for SSI on Medicaid costs of older siblings ( $\mathrm{N}=594)$ by specifying a difference-in-differences approach. We find a null impact of increased income on older sibling's logged annual Medicaid costs (coefficient $=0.007$, standard error $=0.171$ ).

${ }^{12}$ We also find that estimates from quantile regression of Medicaid costs or specialist visits are not significant.
} 
To address the possibility of errors in calculating weight of newborns especially near the 1,200 gram cutoff, we exclude those whose birthweights fall between 1,195 and 1,205 grams (fourth column). The fifth column reports result from a non-parametric local linear regression with a quadratic function of birthweight and triangular kernel function. In the last column, we report results from a regression that excludes all utilization measures and diagnosis indicators before the first three months of life. Month three is the median at which infants below the cutoff were initially awarded SSI before age 1 , so we expect that excluding all outcome measures that occurred before this time should not change the estimated effect of SSI. Overall, across the columns, results are qualitatively similar to our main specification.

In Appendix Table 8, we additionally test whether our sample restriction (continuous enrollment by age 8 ) resulted in selective sampling bias at or around the 1,200-gram cutoff. We find that, among all preterm babies (32 weeks of gestation or earlier) born in 2006-2010 whose birthweight fall between 900 and 1,500 grams $(\mathrm{N}=3,690)$, the low birthweight cutoff is not meaningfully or significantly related to the probability of continuous enrollment in Medicaid by age three, six, or eight. In addition, a coefficient on an interaction between the cutoff and neighborhood median income at birth is insignificant, indicating that neighborhood environment is not significantly associated with the likelihood that children stay longer on Medicaid.

Appendix Table 9 reports main health outcomes by age 3 with study samples varying by different continuous enrollment restrictions. Moving from the sample continuously enrolled in Medicaid for 3 years to the sample continuously enrolled for 8 years, coefficient estimates increase slightly, but, in general, we find that all significant findings remain unchanged.

In Appendix Table 10, we regress initial hospital utilization measures on the low birthweight threshold. Because most preterm and extremely low birthweight babies are initially admitted to 
neonatal intensive care unit, we should find a null impact of increased household unearned income on Medicaid costs for initial hospital stays at birth. Because preterm babies born at 32 weeks or earlier are highly likely to develop respiratory distress due to a deficiency of pulmonary surfactant, initial hospital costs are significantly higher for this population compared to full-term babies. Average hospital costs and length of stay among our study population (preterm infants whose birth weight $\in(900,1200)$ ) are $\$ 105,815$ (median= $\$ 87,831$ ) and 56 days (median=50 days), consistent with estimates from AHRQ (2013) and from Gilbert et al. (2003). ${ }^{13}$ Our results indicate that the 1,200-gram cutoff does not meaningfully or significantly affect initial hospital stays and Medicaid costs, lending support to our finding that the cost-saving effects of SSI do not appear until babies go home.

Appendix Table 11 shows characteristics of complier, never taker, and always taker by applying Abadie's (2003) theorem. Results show that compliers are more likely than the whole sample to be living in higher-socioeconomic level neighborhood (the bottom poverty quartile and the top median income quartile) at birth. This finding, together with the estimated impacts of SSI mobility, provides evidence that eligible children experienced improved neighborhood environment mainly because their families were less likely to move out of high-income neighborhoods than were families whose infants were born above the threshold.

\section{Discussion and Conclusions}

Children in poor families are subject to more and to worse negative early-life shocks (Almond, Currie, 2011). This study finds that crossing the 1,200-gram cutoff for SSI eligibility significantly

\footnotetext{
${ }^{13}$ Average hospital costs and length of stay among all newborns in the U.S. whose birthweights are less than 1,500 grams were \$76,700 and 42.6 days in 2011 (AHRQ, 2013). In California, average hospital costs and length of stay ranged from $\$ 52,000$ to $\$ 92,700$ and 36.5 days to 55.2 days among newborns whose birth weight $\in[1000,1500]$ in 1996 (Gilbert et al., 2003).
} 
increases child SSI enrollment, improves the health of affected children (reduced incidence of malnutrition, infection, injury/burn, and developmental delay), reduces Medicaid costs, and improves neighborhood environments.

The protective health impacts of SSI on infection and malnutrition in early childhood we find are closely in line with Jones et al. (2019), who report that additional income through refundable child benefits in Canada increased household expenditures on non-durable goods such as food and child care. In contrast to the findings of Guldi et al. (2018), our results show that the child health effects of SSI last until at least age 6, despite the fact that the 1,200-gram cutoff is associated with SSI only until age 3, meaning that the effects of SSI may continue past the point of enrollment. ${ }^{14}$

We find that SSI reduces the probability that a child is subject to health shocks in early childhood. In particular, we find evidence that the SSI-related gradients in healthcare utilization are not explained by family's differential response to health shocks ${ }^{15}$, but primarily driven by the fact that SSI reduces the probability that children eligible for SSI experience such health shocks. These findings indicate that SSI's income enhancement effect help affected children enter childhood with fewer chronic conditions, consistent with previous American and Canadian studies (Case et al., 2002; Currie, Stabile, 2003).

Our study provides a strong economic argument for SSI given the high Medicaid cost burden for low birthweight, preterm infants. In our study, Medicaid spent $\$ 5.87$ billion on the $2006-2010$ birth cohort (continuously enrolled in Medicaid for 8 years, $\mathrm{N}=185,022$ ) by age 8 ; within this group, Medicaid costs for the $0.7 \%$ of the cohort who were preterm infants whose birthweight fell between

\footnotetext{
${ }^{14}$ Observed average SSI spells, which seem longer than expectation of Guldi et al. (2018), may be attributed to lags in administrative decision time. Desphande (2016) reported that over $20 \%$ of review cases need at least 1 year for final decision. Also, Hemmeter and Bailey (2015) showed that a majority of children on SSI due to low birthweight received their first CDR decision at age 1-3.

${ }^{15}$ This is especially unlikely given that our study population is all covered by Medicaid.
} 
900 and 1,500 grams $(\mathrm{N}=1,348)$ totaled $\$ 233$ million, that is $4 \%$ of the cohort's total Medicaid spending. Our back-of-the-envelope calculation based on the average monthly SSI benefit (approximately $\$ 600$ ) and the average impacts of the 1,200-gram cutoff on SSI spells by age 8 (10.4 months) indicates that the average SSI benefits provided to these children $(\$ 6,240)$ are far lower than the reduction in Medicaid costs $(\$ 20,510)$ per beneficiary ${ }^{16}$. Our results thus support a growing body of evidence that health shocks that occur in early childhood, which may have longterm negative impacts on health and human capital, ${ }^{17}$ can be remediated by unconditional cash transfers targeting vulnerable children (Almond, Currie, 2011). For example, Desphande (2016) finds that children who stay longer on SSI earn significantly higher lifetime income than those removed from SSI do.

Our results are limited by relatively small sample size, which might contribute to large standard errors and imprecisely estimated coefficients on the impacts on other health outcome measures. We are also limited in our ability to estimate the health impacts in the longer term beyond age 8 . Despite these limitations, our study, using a large cohort of low birthweight infants in New York State, is one of the first to estimate the causal impacts of SSI on child health. We demonstrate that SSI benefits are associated with better health outcomes and lower medical expenditures, suggesting that relatively small cash transfers provided to vulnerable populations may be a costeffective solution to improving health outcomes and reducing health spending.

\footnotetext{
${ }^{16}$ We multiply the estimated impacts of SSI on Medicaid costs by age $8(-29.7 \%$ on average) by the average Medicaid costs incurred after initial hospital discharge of the control group $(\$ 69,057)$.

17 “Healthier children are better learners.” (Heckman, 2007)
} 


\section{References}

Abadie A. 2003. Semiparametric instrumental variable estimation of treatment response models. Journal of Econometrics 113: 231-263.

Agency for Healthcare Research and Quality (AHRQ). 2013. Hospital stays for newborns, 2011. H-CUP statistical brief\#163. https://www.hcup-us.ahrq.gov/reports/statbriefs/sb163.jsp

Aizer A, Eli S, Ferrie J, Lleras-Muney A. 2016. The long-run impact of cash transfers to poor families. American Economic Review 106: 935-971.

Akee R, Copeland W, Costello EJ, Simeonova E. 2018. How does household income affect child personality traits and behaviors? American Economics Review 108: 775-827.

Almond D, Currie J. 2011. Human capital development before age five. In: Handbook of Labor Economics volume 4B (edited by Ashenfelter O, Card D, Layard R). North Holland.

Black SE, Devereux PJ, Salvanes KG. 2007. From the cradle to the labor market? The effect of birth weight on adult outcomes. Quarterly Journal of Economics 122: 409-439.

Case A, Lubotsky D, Paxson C. 2002. Economic status and health in childhood: The origins of the gradient. American Economic Review 92: 1308-1333.

Calonico S, Cattaneo MD, Farrel MH, Titiunik R. 2017. Rdrobust: Software for regression discontinuity designs. Stata Journal 17: 372-404.

Cattaneo MD, Jansson M, Ma X. 2018. Manipulation testing based on density discontinuity. Stata Journal 18: 234-261.

Currie J, Hyson R. 1999. Is the impact of health shocks cushioned by socioeconomic status? The case of low birthweight. American Economic Review 89: 245-250.

Currie J, Stabile M. 2003. Socioeconomic status and child health: Why is the relationship stronger for older children? American Economic Review 93: 1813-1823. 
Daly MC, Burkhauser RV. 2003. The Supplemental Security Income program. In: Means-tested transfer programs in the United States (edited by Moffitt RA). University of Chicago Press.

Desphande M. 2016. Does welfare inhibit success? The long-term effects of removing low-income youth from the disability rolls. American Economic Review 106: 3300-3330.

Duggan MG, Kearney MS. 2007. The impact of child SSI enrollment on household outcomes. Journal of Policy Analysis and Management 26: 861-885.

Gilbert WM, Nesbitt TS, Danielsen B. 2003. The cost of prematurity: Quantification by gestational age and birth weight. Obstetrics \& Gynecology 102: 488-492.

Guldi M, Hawkins A, Hemmeter J, Schmidt L. 2018. Supplemental Security Income and child outcomes: Evidence from birth weight eligibility cutoffs. NBER Working Paper No. 24913.

Heckman JJ. 2007. The economics, technology, and neuroscience of human capability formation. Proceedings of the National Academy of Sciences 104: 13250-13255.

Hemmeter J, Bailey MS. 2015. Childhood continuing disability reviews and age-18 redeterminations for Supplemental Security Income recipients: Outcomes and subsequent program participation. Social Security Administration Research and Statistics Note No. 201503. https://www.ssa.gov/policy/docs/rsnotes/rsn2015-03.pdf

Hoynes HW, Schanzenbach DW. 2018. Safety net investments in children. NBER Working paper No. 24594.

Jones LE, Milligan KS, Stabile M. 2019. Child benefits and family expenditures: Evidence from the national child benefit. Canadian Journal of Economics (forthcoming).

Knox CA, Hampp C, Palmsten K, Zhu Y, Setoguchi S, Brumback B, Segal R, Winterstein AG. 2019. Validation of mother-infant linkage using Medicaid Case ID variable within the Medicaid Analytic eXtract (MAX) database. Pharmacoepidemiology \& Drug Safety 28: 1222-1230. 
Kubik JD. 1999. Incentives for the identification and treatment of children with disabilities: The supplemental security income program. Journal of Public Economics 73: 187-215.

Lee BJ, Mackey-Bilaver L. 2007. Effects of WIC and Food Stamp Program participation on child outcomes. Children and Youth Services Review 29: 501-517.

Leonard J, Mas A. 2008. Welfare reform, time limits, and infant health. Journal of Health Economics 27: 1551-1566.

Milligan K, Stabile M.2011. Do child tax benefits affect the well-being of children? Evidence from Canadian child benefit expansions. American Economic Journal: Economic Policy 3: 175-205.

Phil AM, Basso G. 2019. Did California paid family leave impact infant health? Journal of Policy Analysis and Management 38: 155-180.

Schnitzer PG, Slusher PL, Kruse RL, Tarleton MM. 2011. Identification of ICD codes suggestive of child maltreatment. Child Abuse \& Neglect 35: 3-17.

Social Security Administration. 2019. Annual report of the Supplemental Security Income program. https://www.ssa.gov/OACT/ssir/SSI19/index.html

U.S. Census Bureau. 2019. Income and Poverty in the United States: 2018. https://www.census.gov/data/tables/2019/demo/income-poverty/p60-266.html 

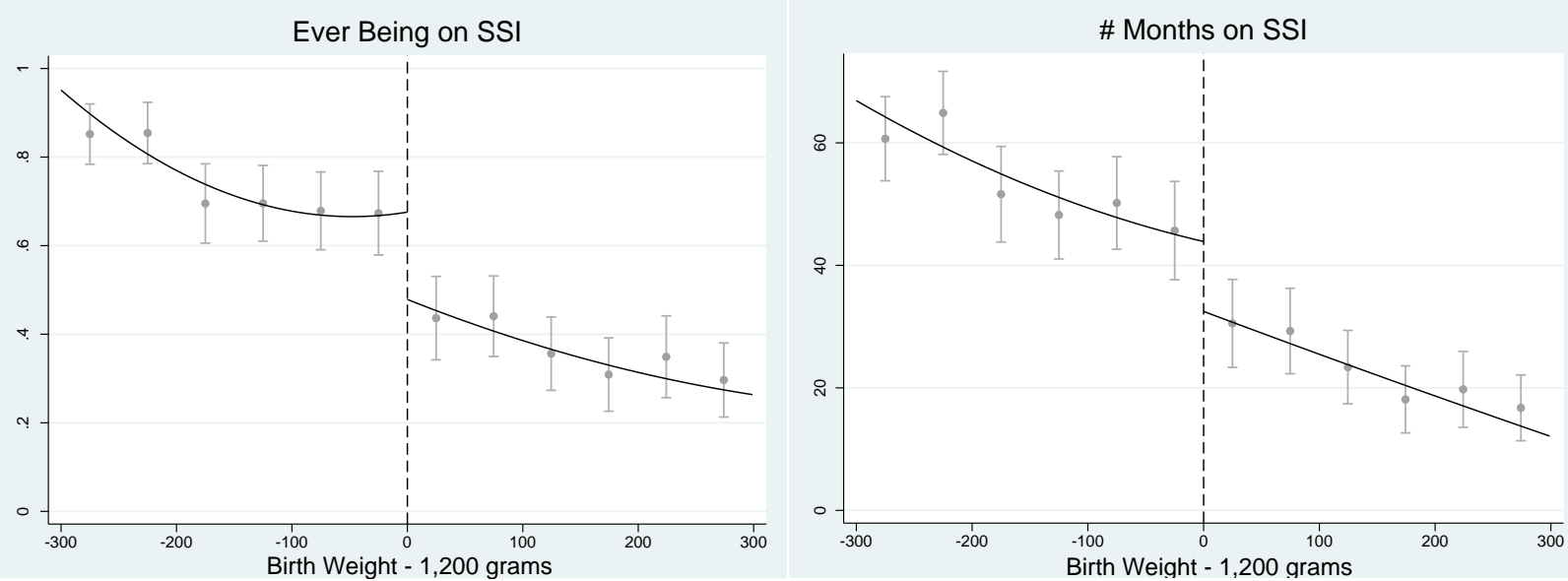

Figure 1. Birthweight (centered at 1,200gram) and SSI enrollment by age 8 .

Figures plot local linear regression fitted lines and 95\% confidence intervals. A 300-gram bandwidth, quadratic function of birthweight, and triangular kernel function are used. 
Table 1. Summary statistics.

\begin{tabular}{lcccc}
\hline & Whole sample & $\begin{array}{c}\text { Birthweight } \in \\
(900,1200)\end{array}$ & $\begin{array}{c}\text { Birthweight } \in \\
(1,200,1500)\end{array}$ & $\begin{array}{c}\text { p-value of } \\
\text { difference }\end{array}$ \\
\hline Birthweight (grams) & $\begin{array}{c}1204.364 \\
(173.017)\end{array}$ & $\begin{array}{c}1046.566 \\
(85.934)\end{array}$ & $\begin{array}{c}1347.430 \\
(85.527)\end{array}$ & $<0.001$ \\
Ever being on SSI by age 1 & 0.367 & 0.587 & 0.168 & $<0.001$ \\
\# months on SSI by age 1 & 3.086 & 5.147 & 1.218 & $<0.001$ \\
Ever being on SSI by age 8 & $(4.677)$ & $(5.211)$ & $(3.125)$ & $<0.001$ \\
\# months on SSI by age 8 & 0.543 & 0.741 & 0.364 & $<0.001$ \\
Female & 37.461 & 53.510 & 22.909 & 0.025 \\
Non-Hispanic White & $(39.628)$ & $(38.894)$ & $(34.336)$ & 0.817 \\
Non-Hispanic Black & 0.467 & 0.435 & 0.496 & 0.224 \\
Hispanic & 0.335 & 0.339 & 0.332 & 0.117 \\
Non-Hispanic other race/ethnicity & 0.071 & 0.081 & 0.207 & 0.178 \\
$\begin{array}{l}\text { Always lived in New York City by } \\
\text { age 8 }\end{array}$ & 0.507 & 0.476 & 0.536 & 0.027 \\
$\begin{array}{l}\text { Always lived in rest of the state by } \\
\text { age 8 }\end{array}$ & 0.465 & 0.493 & 0.440 & 0.051 \\
$\begin{array}{l}\text { Ever moved out of New York City } \\
\text { by age 8 }\end{array}$ & 0.027 & 0.030 & 0.024 & 0.525 \\
$\begin{array}{l}\text { Ever moved into New York City by } \\
\text { age 8 }\end{array}$ & 0.013 & 0.016 & 0.011 & 0.494 \\
Observations & 1348 & 641 & 707 & \\
\hline
\end{tabular}

Study sample includes all infants (continuously enrolled in Medicaid for 8 years since birth) born in New York State in 2006-2010 whose birthweights $\in$ (900gram, 1,500gram). Standard deviation is in parentheses. 
Table 2. Health impacts of SSI: Intent-to-treat analysis.

\begin{tabular}{|c|c|c|c|c|}
\hline & Age $\in[0,3)$ & Age $\in[3,6)$ & Age $\in[6,8)$ & Age $\in[0,8)$ \\
\hline SSI, ever & $\begin{array}{c}0.153^{* * *}(0.052) \\
{[0.284]}\end{array}$ & $\begin{array}{c}0.097 *(0.053) \\
{[0.320]}\end{array}$ & $\begin{array}{c}0.069(0.054) \\
{[0.317]}\end{array}$ & $\begin{array}{c}0.136 * * *(0.051) \\
{[0.364]}\end{array}$ \\
\hline SSI, \# months & $\begin{array}{c}6.076 * * *(1.572) \\
{[5.959]}\end{array}$ & $\begin{array}{c}2.395(1.807) \\
{[10.052]}\end{array}$ & $\begin{array}{c}1.961(1.227) \\
{[6.899]}\end{array}$ & $\begin{array}{c}10.431 * *(4.148) \\
{[22.909]}\end{array}$ \\
\hline Malnutrition & $\begin{array}{c}-0.033^{* *}(0.013) \\
{[0.021]}\end{array}$ & $\begin{array}{c}-0.008(0.008) \\
{[0.008]}\end{array}$ & $\begin{array}{c}0.013 *(0.007) \\
{[0.004]}\end{array}$ & $\begin{array}{c}-0.015(0.015) \\
{[0.027]}\end{array}$ \\
\hline $\begin{array}{l}\text { Respiratory tract } \\
\text { infection }\end{array}$ & $\begin{array}{c}-0.050(0.034) \\
{[0.902]}\end{array}$ & $\begin{array}{c}-0.047(0.046) \\
{[0.769]}\end{array}$ & $\begin{array}{c}0.013(0.029) \\
{[0.123]}\end{array}$ & $\begin{array}{c}-0.036(0.022) \\
{[0.960]}\end{array}$ \\
\hline Digestive diseases & $\begin{array}{c}-0.081 *(0.046) \\
{[0.751]}\end{array}$ & $\begin{array}{c}0.042(0.056) \\
{[0.537]}\end{array}$ & $\begin{array}{c}-0.002(0.054) \\
{[0.365]}\end{array}$ & $\begin{array}{c}0.009(0.032) \\
{[0.891]}\end{array}$ \\
\hline Urinary tract infection & $\begin{array}{c}-0.064 * *(0.030) \\
{[0.079]}\end{array}$ & $\begin{array}{c}-0.004(0.024) \\
{[0.047]}\end{array}$ & $\begin{array}{c}0.009(0.013) \\
{[0.014]}\end{array}$ & $\begin{array}{c}-0.054(0.036) \\
{[0.126]}\end{array}$ \\
\hline Injury/Burn & $\begin{array}{c}-0.008(0.056) \\
{[0.475]}\end{array}$ & $\begin{array}{c}0.064(0.056) \\
{[0.388]}\end{array}$ & $\begin{array}{c}-0.020(0.032) \\
{[0.113]}\end{array}$ & $\begin{array}{c}0.024(0.052) \\
{[0.655]}\end{array}$ \\
\hline Developmental delay & $\begin{array}{c}-0.034(0.048) \\
{[0.679]}\end{array}$ & $\begin{array}{c}-0.111^{* *}(0.053) \\
{[0.358]}\end{array}$ & $\begin{array}{c}-0.014(0.037) \\
{[0.141]}\end{array}$ & $\begin{array}{c}-0.040(0.046) \\
{[0.726]}\end{array}$ \\
\hline $\begin{array}{l}\text { Early } \\
\text { intervention/Special } \\
\text { education }{ }^{\#}\end{array}$ & $\begin{array}{c}-0.052(0.048) \\
{[0.659]}\end{array}$ & $\begin{array}{c}-0.099 *(0.053) \\
{[0.344]}\end{array}$ & $\begin{array}{c}-0.054(0.048) \\
{[0.242]}\end{array}$ & $\begin{array}{c}-0.061(0.046) \\
{[0.702]}\end{array}$ \\
\hline $\begin{array}{l}\text { Logged Medicaid costs } \\
(2009 \$)^{\wedge}\end{array}$ & $\begin{array}{c}-0.238 * *(0.101) \\
{[\$ 120323]}\end{array}$ & $\begin{array}{c}-0.284 *(0.152) \\
{[\$ 20952]}\end{array}$ & $\begin{array}{c}-0.304 *(0.178) \\
{[\$ 11366]}\end{array}$ & $\begin{array}{c}-0.260 * * *(0.098) \\
{[\$ 152642]}\end{array}$ \\
\hline
\end{tabular}

$\mathrm{N}=1,348$.

\# Indicator for enrolling in the early intervention or individualized education program, which includes physical therapy, speech therapy, vision services, nutrition services, psychological services, for infants/children with disabilities or developmental delay. Services are provided free of charge without doctor's referral required.

${ }^{\wedge}$ Value of 1 is assigned to those with zero cost.

Robust standard errors are in parentheses. Control group means are in brackets. The 1,200-gram cutoff is used to estimate intent-to-treat effects of SSI on the probability of being diagnosed with indicated disease groups. Each cell represents separate regression results. Above parametric linear regressions also include birthweight spline, an interaction between birthweight spline and the 1,200 cutoff, birth month and year fixed effects, race/ethnicity indicators (White, black, Hispanic, others), female indicator, and full interactions between birth cohort fixed effects, gender, race/ethnicity.

$*, * *, * * *$ : significant at $<0.1,<0.05,<0.001$. 
Table 3. Impacts of SSI on healthcare utilization: Intent-to-treat analysis.

\begin{tabular}{|c|c|c|c|c|}
\hline & Age $\in[0,3)$ & Age $\in[3,6)$ & Age $\in[6,8)$ & Age $\in[0,8)$ \\
\hline $\begin{array}{l}\text { Logged Medicaid } \\
\text { costs }(2009 \$)^{\wedge}\end{array}$ & $\begin{array}{c}-0.238 * *(0.101) \\
{[\$ 120323]}\end{array}$ & $\begin{array}{c}-0.284 *(0.152) \\
{[\$ 20952]}\end{array}$ & $\begin{array}{c}-0.304 *(0.178) \\
{[\$ 11366]}\end{array}$ & $\begin{array}{c}-0.260 * * *(0.098) \\
{[\$ 152642]}\end{array}$ \\
\hline Hospitalization, ever & $\begin{array}{c}-0.106 * *(0.052) \\
{[0.720]}\end{array}$ & $\begin{array}{c}-0.026(0.043) \\
{[0.154]}\end{array}$ & $\begin{array}{c}-0.031(0.032) \\
{[0.095]}\end{array}$ & $\begin{array}{c}-0.082 *(0.049) \\
{[0.762]}\end{array}$ \\
\hline \# hospitalization & $\begin{array}{c}-0.272(0.229) \\
{[1.769]}\end{array}$ & $\begin{array}{c}-0.090(0.099) \\
{[0.252]}\end{array}$ & $\begin{array}{c}-0.043(0.056) \\
{[0.126]}\end{array}$ & $\begin{array}{c}-0.405(0.329) \\
{[2.147]}\end{array}$ \\
\hline $\begin{array}{l}\text { Length of stay, sum } \\
\text { (days) }^{\#}\end{array}$ & $\begin{array}{c}-12.519 * *(6.274) \\
{[38.349]}\end{array}$ & $\begin{array}{c}-1.046^{*}(0.567) \\
{[0.950]}\end{array}$ & $\begin{array}{c}-1.465^{*}(0.282) \\
{[0.717]}\end{array}$ & $\begin{array}{c}-15.030 * *(6.850) \\
{[40.017]}\end{array}$ \\
\hline $\begin{array}{l}\text { Hospitalization for } \\
\text { infection }\end{array}$ & $\begin{array}{c}-0.013(0.024) \\
{[0.034]}\end{array}$ & $\begin{array}{c}0.003(0.006) \\
{[0.003]}\end{array}$ & $\begin{array}{c}-0.009(0.009) \\
{[0.004]}\end{array}$ & $\begin{array}{c}-0.021(0.026) \\
{[0.041]}\end{array}$ \\
\hline $\begin{array}{l}\text { Hospitalization for } \\
\text { nutritional, metabolic } \\
\text { disorders }\end{array}$ & $\begin{array}{c}-0.035(0.024) \\
{[0.048]}\end{array}$ & $\begin{array}{c}0.010(0.011) \\
{[0.006]}\end{array}$ & $\begin{array}{c}-0.011(0.010) \\
{[0.007]}\end{array}$ & $\begin{array}{c}-0.027(0.027) \\
{[0.054]}\end{array}$ \\
\hline $\begin{array}{l}\text { Hospitalization for } \\
\text { respiratory diseases }\end{array}$ & $\begin{array}{c}0.021(0.053) \\
{[0.310]}\end{array}$ & $\begin{array}{c}-0.016(0.031) \\
{[0.091]}\end{array}$ & $\begin{array}{c}0.030(0.022) \\
{[0.034]}\end{array}$ & $\begin{array}{c}0.023(0.054) \\
{[0.313]}\end{array}$ \\
\hline $\begin{array}{l}\text { Hospitalization for } \\
\text { digestive diseases }\end{array}$ & $\begin{array}{c}-0.018(0.035) \\
{[0.108]}\end{array}$ & (no cases) & $\begin{array}{c}-0.0005(0.009) \\
{[0.008]}\end{array}$ & $\begin{array}{c}-0.014(0.038) \\
{[0.100]}\end{array}$ \\
\hline $\begin{array}{l}\text { Hospitalization for } \\
\text { genitourinary tract } \\
\text { diseases }\end{array}$ & $\begin{array}{c}-0.025^{* *}(0.012) \\
{[0.012]}\end{array}$ & $\begin{array}{c}-0.012(0.008) \\
{[0.005]}\end{array}$ & $\begin{array}{c}-0.0001(0.006) \\
{[0.004]}\end{array}$ & $\begin{array}{c}-0.036 * *(0.015) \\
{[0.021]}\end{array}$ \\
\hline $\begin{array}{l}\text { Hospitalization for } \\
\text { sensory organ } \\
\text { diseases }\end{array}$ & $\begin{array}{c}-0.002(0.024) \\
{[0.051]}\end{array}$ & $\begin{array}{c}-0.040 * *(0.019) \\
{[0.035]}\end{array}$ & $\begin{array}{c}-0.005(0.015) \\
{[0.020]}\end{array}$ & $\begin{array}{c}-0.041(0.030) \\
{[0.083]}\end{array}$ \\
\hline $\begin{array}{l}\text { Hospitalization due to } \\
\text { injury/burn }\end{array}$ & $\begin{array}{c}-0.052 * *(0.025) \\
{[0.047]}\end{array}$ & $\begin{array}{c}-0.006(0.014) \\
{[0.016]}\end{array}$ & $\begin{array}{c}-0.010(0.012) \\
{[0.010]}\end{array}$ & $\begin{array}{c}-0.049 *(0.029) \\
{[0.072]}\end{array}$ \\
\hline \# specialist visits & $\begin{array}{c}-4.837 * * *(1.417) \\
{[8.025]}\end{array}$ & $\begin{array}{c}-2.166^{* *}(1.043) \\
{[5.359]}\end{array}$ & $\begin{array}{c}-2.067(1.275) \\
{[4.228]}\end{array}$ & $\begin{array}{c}-9.070 * * *(2.816) \\
{[17.612]}\end{array}$ \\
\hline
\end{tabular}

$\mathrm{N}=1,348$.

${ }^{\wedge}$ Value of 1 was assigned to those with zero cost.

Robust standard errors are in parentheses. Control group means are in brackets. Each cell represents separate regression results. Regressions include the same covariates as in Table 2. Hospitalization cases exclude initial stays at birth.

*, **, ***: significant at $<0.1,<0.05,<0.001$. 
Table 4. SSI and new chronic conditions.

\begin{tabular}{lcccc}
\hline & $\begin{array}{c}\text { Earliest diagnosis of } \\
\text { chronic condition (age } \\
\text { at months) }\end{array}$ & Age $\in[0,3)$ & Age $\in[3,6)$ & Age $\in[6,8)$ \\
\cline { 3 - 5 } Below the cutoff & 1.722 & $-0.208^{* *}$ & 0.039 & -0.015 \\
Control group mean & $(1.875)$ & $(0.102)$ & $(0.050)$ & $(0.031)$ \\
& 14.860 & 1.390 & 0.242 & 0.107 \\
\hline
\end{tabular}

$\mathrm{N}=1,348$.

Robust standard errors are in parentheses. Each cell represents separate regression results. Regressions include the same covariates as in Table 2. Chronic conditions include malnutrition, anemia, obesity, vision defect, hearing defect, asthma, genitourinary tract diseases, and developmental delay.

$*$, **, ***: significant at $<0.1,<0.05,<0.001$. 
Table 5. Effects of earlier health shocks on current healthcare utilization.

\begin{tabular}{lcccc}
\hline & \multicolumn{4}{c}{ Healthcare utilization during age $\in[3,6]$} \\
\cline { 2 - 5 } & $\begin{array}{c}\text { Logged } \\
\text { Medicaid costs }\end{array}$ & \# hospitalization & $\begin{array}{c}\text { Length of } \\
\text { stay, sum }\end{array}$ & $\begin{array}{c}\text { \# specialist } \\
\text { visits }\end{array}$ \\
\hline Below the cutoff & -0.224 & -0.076 & $-1.179 * *$ & -1.728 \\
& $(0.175)$ & $(0.099)$ & $(0.541)$ & $(1.159)$ \\
Chronic conditions diagnosed & $\begin{array}{c}0.473^{* * *} \\
(0.060)\end{array}$ & $0.136^{* * *}$ & $0.460^{*}$ & $1.902^{* * *}$ \\
by age 3 & $(0.043)$ & $(0.274)$ & $(0.471)$ \\
$\begin{array}{l}\text { Below the cutoff * Chronic } \\
\text { conditions diagnosed by age 3 }\end{array}$ & $(0.027$ & 0.010 & 0.159 & -0.030 \\
\hline
\end{tabular}

$\mathrm{N}=1,348$.

${ }^{\wedge}$ Value of 1 was assigned to those with zero cost.

Robust standard errors are in parentheses. Each cell represents separate regression results. Regressions include the same covariates as in Table 2. Chronic conditions include malnutrition, anemia, obesity, vision defect, hearing defect, asthma, genitourinary tract diseases, and developmental delay.

$*$, **, ***: significant at $<0.1,<0.05,<0.001$. 
Table 6. The effects of SSI on cumulative mobility by age 8 .

\begin{tabular}{|c|c|c|}
\hline & $\begin{array}{c}\text { Coefficient on } \\
\text { birthweight } \in(900,1200) \\
\end{array}$ & $\begin{array}{c}\text { Control } \\
\text { group mean }\end{array}$ \\
\hline Moved, ever ${ }^{\#}$ & $0.017(0.055)$ & 0.591 \\
\hline$\#$ Moves $^{\#}$ & $0.308(0.328)$ & 1.907 \\
\hline Logged distance moved (miles) ${ }^{\wedge}$ & $-0.004(0.090)$ & 4.995 miles \\
\hline Moved into New York City, ever & $-0.008(0.013)$ & 0.011 \\
\hline Moved out of New York City, ever & $-0.020(0.017)$ & 0.024 \\
\hline Changes in census tract-level poverty rate $(\%)^{\&}$ & $-2.726(1.905)$ & -1.938 \\
\hline $\begin{array}{l}\text { Changes in census tract-level median household income } \\
(2009 \$)^{\&}\end{array}$ & $8585.413 * *(3435.310)$ & $\$ 5518$ \\
\hline $\begin{array}{l}\text { Changes in census tract-level education attainment: High } \\
\text { school completion }(\%)^{\&}\end{array}$ & $1.306(1.780)$ & 7.045 \\
\hline $\begin{array}{l}\text { Changes in census tract-level education attainment: } \\
\text { Bachelor degree }(\%)^{\&}\end{array}$ & $4.079 *(2.146)$ & 6.700 \\
\hline
\end{tabular}

$\mathrm{N}=1,348$.

\# Enrollees whose zip codes changed during the study period.

${ }^{\wedge}$ Value of 1 was assigned to those whose zip codes never changed.

\& Comparisons between the 2009 American Community Survey (for places of birth in 2006-2010) and the 2017 American Community Survey (for places at age of 8) 5-year estimates at census tract level. Robust standard errors are in parentheses. Control group means are in brackets. Each cell represents separate regression results. Regressions include the same covariates as in Table 2.

$*, * *, * * *$ : significant at $<0.1,<0.05,<0.001$. 
Table 7. The effects of SSI on cumulative maternal health outcomes and fertility until 8 years since birth.

\begin{tabular}{lcc}
\hline & $\begin{array}{c}\text { Coefficient on birthweight } \in \\
(900,1200)\end{array}$ & $\begin{array}{c}\text { Control group } \\
\text { mean }\end{array}$ \\
\hline Mental illnesses, all & $-0.008(0.049)$ & 0.724 \\
Anxiety & $-0.035(0.044)$ & 0.294 \\
Mood disorder & $0.009(0.032)$ & 0.089 \\
Substance-related disorder & $0.012(0.025)$ & 0.061 \\
Alcohol-related disorder & $-0.007(0.016)$ & 0.033 \\
Pregnancy & $-0.045(0.042)$ & 0.808 \\
Contraceptive utilization & $-0.046(0.046)$ & 0.753 \\
Logged Medicaid cost (2009\$) & $-0.080(0.088)$ & $\$ 39097$ \\
Hospitalization, ever & $-0.012(0.040)$ & 0.827 \\
\# hospitalization & $-0.102(0.131)$ & 1.781 \\
\# specialist visits & $0.316(1.911)$ & 11.153 \\
\hline
\end{tabular}

$\mathrm{N}=1,268$.

${ }^{\wedge}$ Value of 1 was assigned to those with zero cost.

Robust standard errors are in parentheses. Control group means are in brackets. We link the 2006-2010 cohort to their biological mothers by using administrative case numbers and birth dates. Each cell represents separate regression results. Regressions include mother's age at birth as well as the same covariates as in Table 2 . $*$, **, ***: significant at $<0.1,<0.05,<0.001$. 
Table 8. Distributional effects of SSI by age 8: Quantile regression.

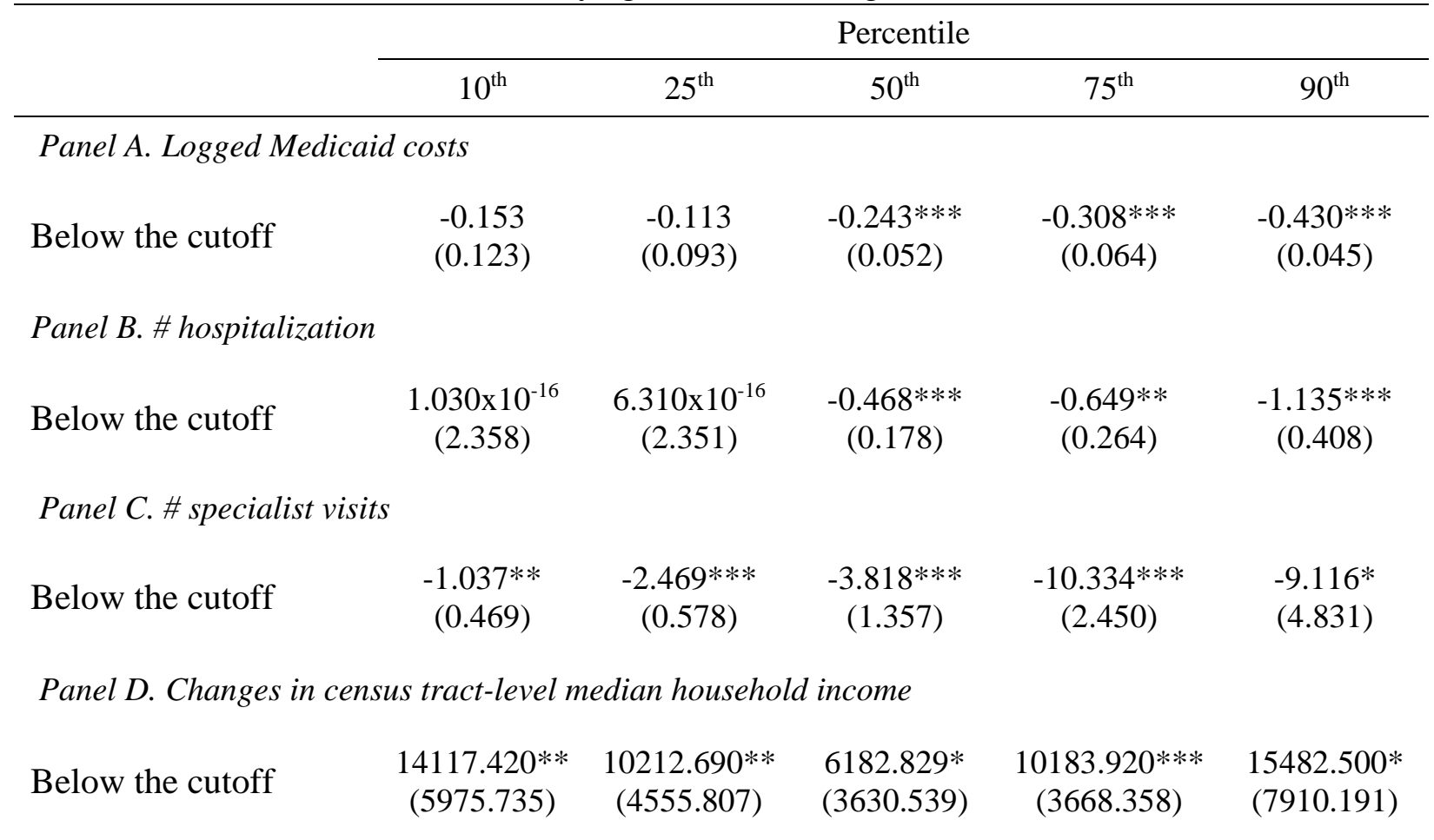

$\mathrm{N}=1,348$.

Robust standard errors are in parentheses. Each cell represents separate regression results. Regressions include the same covariates as in Table 2.

$*, * *, * *$ : significant at $<0.1,<0.05,<0.001$. 
Table 9. Robustness check: Alternative specifications on the effects of SSI on cumulative prevalence of main health outcomes by age 8.

\begin{tabular}{|c|c|c|c|c|c|c|}
\hline & Main specification & $\begin{array}{c}\text { Bandwidth: } 250 \\
\text { grams }\end{array}$ & $\begin{array}{c}\text { Sample without } \\
\text { preterm restriction }\end{array}$ & $\begin{array}{c}\text { Excluding } \\
\text { birthweight } \in \\
{[1195,1205]} \\
\end{array}$ & $\begin{array}{c}\text { Non-parametric } \\
\text { local linear } \\
\text { regression }\end{array}$ & $\begin{array}{c}\text { Excluding } \\
\text { utilization during } \\
\text { the first } 3 \text { months }\end{array}$ \\
\hline SSI, ever & $0.136 * * *(0.051)$ & $0.126^{* *}(0.057)$ & $0.165^{* * *}(0.044)$ & $0.128 * *(0.053)$ & $0.197 * *(0.091)$ & $0.136 * * *(0.051)$ \\
\hline SSI, \# months & $10.431^{* *}(4.148)$ & $8.493 *(4.587)$ & $12.630 * * *(0.012)$ & $10.196 * *(4.310)$ & $11.387 *(6.860)$ & $10.431^{* *}(4.148)$ \\
\hline Malnutrition & $-0.015(0.015)$ & $-0.023(0.018)$ & $-0.011(0.014)$ & $-0.019(0.016)$ & $-0.031 *(0.017)$ & $-0.015(0.015)$ \\
\hline $\begin{array}{l}\text { Upper respiratory } \\
\text { tract infection }\end{array}$ & $-0.058 * *(0.028)$ & $-0.057 *(0.031)$ & $-0.018(0.026)$ & $-0.069 * *(0.029)$ & $-0.042(0.048)$ & $-0.077 * * *(0.030)$ \\
\hline $\begin{array}{l}\text { Urinary tract } \\
\text { infection }\end{array}$ & $-0.054(0.036)$ & $-0.055(0.040)$ & $-0.047(0.030)$ & $-0.054(0.038)$ & $-0.039(0.058)$ & $-0.037(0.035)$ \\
\hline Burn & $-0.056^{* *}(0.022)$ & $-0.038(0.024)$ & $-0.041 * *(0.018)$ & $-0.056 * *(0.023)$ & $-0.014(0.032)$ & $-0.053 * *(0.022)$ \\
\hline $\begin{array}{l}\text { Developmental } \\
\text { delay }\end{array}$ & $-0.040(0.046)$ & $-0.012(0.051)$ & $-0.035(0.040)$ & $-0.050(0.047)$ & $-0.055(0.079)$ & $-0.030(0.047)$ \\
\hline Special education & $-0.061(0.046)$ & $-0.064(0.051)$ & $-0.052(0.040)$ & $-0.059(0.048)$ & $-0.107(0.080)$ & $-0.052(0.048)$ \\
\hline $\begin{array}{l}\text { Logged Medicaid } \\
\text { costs }(2009 \$)^{\wedge}\end{array}$ & $-0.260 * * *(0.098)$ & $-0.229 * *(0.110)$ & $-0.262 * * *(0.087)$ & $-0.220 * *(0.101)$ & $-0.218(0.168)$ & $-0.313 * *(0.121)$ \\
\hline Hospitalization, ever & $-0.082 *(0.049)$ & $-0.091 *(0.055)$ & $-0.075^{*}(0.042)$ & $-0.061(0.050)$ & $-0.154 *(0.083)$ & $-0.063(0.060)$ \\
\hline \# specialist visits & $-9.070 * * *(2.816)$ & $-9.457 * * *(3.044)$ & $-7.983 * * *(2.278)$ & $\begin{array}{c}-9.833 * * * \\
(2.981)\end{array}$ & $-5.623(3.935)$ & $-8.988 * * *(2.613)$ \\
\hline Observations & 1348 & 1122 & 1871 & 1326 & 1348 & 1348 \\
\hline
\end{tabular}

\# A 300-gram bandwidth, quadratic function of birthweight, and triangular kernel function are used.

${ }^{\wedge}$ Value of 1 was assigned to those with zero cost.

Robust standard errors are in parentheses. Each cell represents separate regression results. Regressions include the same covariates as in Table 2.

$*$, **, $* * *$ : significant at $<0.1,<0.05,<0.001$. 
Appendix Table 1. SSI take-up by age 1 classified by demographics.

\begin{tabular}{lccc}
\hline & $\begin{array}{c}\text { Birthweight } \in(900, \\
1200)\end{array}$ & $\begin{array}{c}\text { Birthweight } \in \\
(1,200,1500)\end{array}$ & $\begin{array}{c}\text { p-value of } \\
\text { difference }\end{array}$ \\
\hline Panel A. Ever being on SSI by age 8 & & & \\
Girls (N=630) & 0.545 & 0.114 & $<0.001$ \\
Boys (N=718) & 0.619 & 0.222 & $<0.001$ \\
Non-Hispanic White (N=452) & 0.714 & 0.196 & $<0.001$ \\
Non-Hispanic Black (N=296) & 0.600 & 0.205 & $<0.001$ \\
Hispanic (N=417) & 0.492 & 0.142 & $<0.001$ \\
Non-Hispanic other (N=96) & 0.538 & 0.091 & $<0.001$ \\
New York City (N=684) & 0.521 & 0.164 & $<0.001$ \\
Rest of the state (N=627) & 0.655 & 0.177 & $<0.001$ \\
Panel B. \# months on SSI by age 8 & & & $<0.001$ \\
Girls (N=630) & $4.742(5.190)$ & $0.755(2.504)$ & $<0.001$ \\
Boys (N=718) & $5.459(5.212)$ & $1.674(3.580)$ & $<0.001$ \\
Non-Hispanic White (N=452) & $6.535(5.293)$ & $1.481(3.526)$ & $<0.001$ \\
Non-Hispanic Black (N=296) & $5.407(5.316)$ & $1.623(3.531)$ & $<0.001$ \\
Hispanic (N=417) & $4.135(0.360)$ & $0.897(2.550)$ & $<0.001$ \\
Non-Hispanic other (N=96) & $4.269(4.487)$ & $0.818(2.730)$ & $<0.001$ \\
New York City (N=684) & $4.482(5.053)$ & $1.135(3.005)$ & $<0.001$ \\
Rest of the state (N=627) & $5.832(5.283)$ & $1.318(3.247)$ &
\end{tabular}

Study sample includes all infants (continuously enrolled in Medicaid for 8 years since birth) born in New York State in 2006-2010 whose birthweights $\in$ (900gram, 1,500gram). Standard deviation is in parentheses. 
Appendix Table 2. First stage results by age.

\begin{tabular}{lcc} 
& Coefficient on birthweight $\in(900,1200)$ & Control group mean \\
\hline Age $\in[0,1)$ & $1.788^{* * *}(0.508)$ & 1.218 \\
Age $\in[1,2)$ & $2.292^{* * *}(0.590)$ & 2.026 \\
Age $\in[2,3)$ & $1.995^{* * *}(0.614)$ & 2.716 \\
Age $\in[3,4)$ & $0.941(0.623)$ & 3.204 \\
Age $\in[4,5)$ & $0.580(0.631)$ & 3.407 \\
Age $\in[5,6)$ & $0.874(0.630)$ & 3.441 \\
Age $\in[6,7)$ & $0.971(0.627)$ & 3.499 \\
Age $\in[7,8)$ & $0.990(0.622)$ & 3.399 \\
\hline
\end{tabular}

$\mathrm{N}=1,348$.

Robust standard errors are in parentheses. Control group means are in brackets. Each cell represents separate regression results. Regressions include the same covariates as in Table 2 .

$*, * *, * * *$ : significant at $<0.1,<0.05,<0.001$. 
Appendix Table 3. SSI receipt trajectory by age 8 .

\begin{tabular}{|c|c|c|c|c|c|c|c|c|}
\hline $\begin{array}{c}\text { Earliest } \\
\text { enrollment in SSI }\end{array}$ & Observations & $\begin{array}{l}\text { Continuously } \\
\text { enrolled in } \\
\text { SSI by age } 2 \\
\end{array}$ & $\begin{array}{l}\text { Continuously } \\
\text { enrolled in } \\
\text { SSI by age } 3 \\
\end{array}$ & $\begin{array}{l}\text { Continuously } \\
\text { enrolled in } \\
\text { SSI by age } 4 \\
\end{array}$ & $\begin{array}{l}\text { Continuously } \\
\text { enrolled in } \\
\text { SSI by age } 5\end{array}$ & $\begin{array}{l}\text { Continuously } \\
\text { enrolled in } \\
\text { SSI by age } 6 \\
\end{array}$ & $\begin{array}{l}\text { Continuously } \\
\text { enrolled in } \\
\text { SSI by age } 7\end{array}$ & $\begin{array}{l}\text { Continuously } \\
\text { enrolled in } \\
\text { SSI by age } 8 \\
\end{array}$ \\
\hline \multicolumn{9}{|c|}{ Panel A. Birthweight $\in(900,1200)$} \\
\hline Never & 166 (25.9\%) & - & - & - & - & - & - & - \\
\hline Age $\in[0,1)$ & $376(58.7 \%)$ & 0.774 & 0.660 & 0.566 & 0.487 & 0.426 & 0.351 & 0.295 \\
\hline Age $\in[1,2)$ & $65(10.1 \%)$ & - & 0.862 & 0.785 & 0.708 & 0.600 & 0.554 & 0.477 \\
\hline Age $\in[2,3)$ & $11(1.7 \%)$ & - & - & 0.909 & 0.818 & 0.727 & 0.636 & 0.636 \\
\hline Age $\in[3,4)$ & $7(1.1 \%)$ & - & - & - & 0.857 & 0.714 & 0.714 & 0.571 \\
\hline Age $\in[4,5)$ & $5(0.8 \%)$ & - & - & - & - & 0.800 & 0.600 & 0.600 \\
\hline Age $\in[5,6)$ & $6(0.9 \%)$ & - & - & - & - & - & 0.833 & 0.833 \\
\hline Age $\in[6,7)$ & $5(0.8 \%)$ & - & - & - & - & - & - & 0.400 \\
\hline Age $\in[7,8)$ & 0 & - & - & - & - & - & - & - \\
\hline \multicolumn{9}{|c|}{ Panel B. Birthweight $\in(1200,1500)$} \\
\hline Never & $450(63.7 \%)$ & - & - & - & - & - & - & - \\
\hline Age $\in[0,1)$ & $119(16.8 \%)$ & 0.773 & 0.723 & 0.664 & 0.563 & 0.496 & 0.420 & 0.353 \\
\hline Age $\in[1,2)$ & $41(5.8 \%)$ & - & 0.902 & 0.854 & 0.829 & 0.756 & 0.732 & 0.659 \\
\hline Age $\in[2,3)$ & $41(5.8 \%)$ & - & - & 0.951 & 0.927 & 0.902 & 0.829 & 0.756 \\
\hline Age $\in[3,4)$ & $24(3.4 \%)$ & - & - & - & 0.917 & 0.917 & 0.875 & 0.708 \\
\hline Age $\in[4,5)$ & $12(1.7 \%)$ & - & - & - & - & 0.833 & 0.750 & 0.750 \\
\hline Age $\in[5,6)$ & $6(0.8 \%)$ & - & - & - & - & - & 1 & 1 \\
\hline Age $\in[6,7)$ & $6(0.8 \%)$ & - & - & - & - & - & - & 0.667 \\
\hline Age $\in[7,8)$ & $8(1.1 \%)$ & - & - & - & - & - & - & - \\
\hline
\end{tabular}

$\mathrm{N}=641$ (below the cutoff) \& 707 (above the cutoff). 
Appendix Table 4. Health impacts of SSI: Full panel of results.

\begin{tabular}{|c|c|c|c|c|}
\hline & Age $\in[0,3)$ & Age $\in[3,6)$ & Age $\in[6,8)$ & Age $\in[0,8)$ \\
\hline SSI, ever & $\begin{array}{c}0.153^{* * *}(0.052) \\
{[0.284]}\end{array}$ & $\begin{array}{c}0.097 *(0.053) \\
{[0.320]}\end{array}$ & $\begin{array}{c}0.069(0.054) \\
{[0.317]}\end{array}$ & $\begin{array}{c}0.136 * * *(0.051) \\
{[0.364]}\end{array}$ \\
\hline SSI, \# months & $\begin{array}{c}6.076^{* * *}(1.572) \\
{[5.959]}\end{array}$ & $\begin{array}{c}2.395(1.807) \\
{[10.052]}\end{array}$ & $\begin{array}{l}1.961(1.227) \\
{[6.899]}\end{array}$ & $\begin{array}{c}10.431 * *(4.148) \\
{[22.909]}\end{array}$ \\
\hline $\begin{array}{l}\text { Fever of unknown } \\
\text { origin }\end{array}$ & $\begin{array}{c}-0.030(0.056) \\
{[0.438]}\end{array}$ & $\begin{array}{c}-0.099 * *(0.050) \\
{[0.270]}\end{array}$ & $\begin{array}{c}0.028 *(0.016) \\
{[0.025]}\end{array}$ & $\begin{array}{c}-0.046(0.056) \\
{[0.553]}\end{array}$ \\
\hline Malnutrition & $\begin{array}{c}-0.033^{* *}(0.013) \\
{[0.021]}\end{array}$ & $\begin{array}{c}-0.008(0.008) \\
{[0.008]}\end{array}$ & $\begin{array}{c}0.013 *(0.007) \\
{[0.004]}\end{array}$ & $\begin{array}{c}-0.015(0.015) \\
{[0.027]}\end{array}$ \\
\hline Anemia & $\begin{array}{c}-0.016(0.044) \\
{[0.177]}\end{array}$ & $\begin{array}{c}-0.012(0.027) \\
{[0.081]}\end{array}$ & $\begin{array}{c}-0.002(0.009) \\
{[0.014]}\end{array}$ & $\begin{array}{c}-0.011(0.046) \\
{[0.218]}\end{array}$ \\
\hline Obesity & $\begin{array}{c}-0.013(0.020) \\
{[0.025]}\end{array}$ & $\begin{array}{c}0.025(0.029) \\
{[0.074]}\end{array}$ & $\begin{array}{c}-0.039(0.030) \\
{[0.095]}\end{array}$ & $\begin{array}{c}-0.023(0.037) \\
{[0.136]}\end{array}$ \\
\hline Vision defect & $\begin{array}{c}0.030(0.038) \\
{[0.146]}\end{array}$ & $\begin{array}{c}-0.011(0.050) \\
{[0.240]}\end{array}$ & $\begin{array}{c}-0.008(0.022) \\
{[0.042]}\end{array}$ & $\begin{array}{c}-0.015(0.052) \\
{[0.330]}\end{array}$ \\
\hline Hearing impairment & $\begin{array}{c}-0.014(0.047) \\
{[0.204]}\end{array}$ & $\begin{array}{c}-0.006(0.036) \\
{[0.112]}\end{array}$ & $\begin{array}{c}0.008(0.012) \\
{[0.014]}\end{array}$ & $\begin{array}{c}0.011(0.051) \\
{[0.256]}\end{array}$ \\
\hline $\begin{array}{l}\text { Upper respiratory tract } \\
\text { infection }\end{array}$ & $\begin{array}{c}-0.058(0.042) \\
{[0.829]}\end{array}$ & $\begin{array}{c}-0.077(0.048) \\
{[0.744]}\end{array}$ & $\begin{array}{l}0.015(0.028) \\
{[0.115]}\end{array}$ & $\begin{array}{c}-0.058 * *(0.028) \\
{[0.926]}\end{array}$ \\
\hline $\begin{array}{l}\text { Lower respiratory tract } \\
\text { infection }\end{array}$ & $\begin{array}{c}-0.038(0.056) \\
{[0.545]}\end{array}$ & $\begin{array}{c}0.033(0.048) \\
{[0.225]}\end{array}$ & $\begin{array}{c}-0.009(0.014) \\
{[0.024]}\end{array}$ & $\begin{array}{c}-0.041(0.053) \\
{[0.634]}\end{array}$ \\
\hline Asthma & $\begin{array}{c}-0.042(0.055) \\
{[0.396]}\end{array}$ & $\begin{array}{c}-0.003(0.054) \\
{[0.341]}\end{array}$ & $\begin{array}{c}0.042(0.032) \\
{[0.105]}\end{array}$ & $\begin{array}{c}-0.037(0.055) \\
{[0.506]}\end{array}$ \\
\hline $\begin{array}{l}\text { Diseases of the } \\
\text { digestive system }\end{array}$ & $\begin{array}{c}-0.081 *(0.046) \\
{[0.751]}\end{array}$ & $\begin{array}{c}0.042(0.056) \\
{[0.537]}\end{array}$ & $\begin{array}{c}-0.002(0.054) \\
{[0.365]}\end{array}$ & $\begin{array}{c}0.009(0.032) \\
{[0.891]}\end{array}$ \\
\hline $\begin{array}{l}\text { Diseases of the } \\
\text { genitourinary system }\end{array}$ & $\begin{array}{c}-0.083^{* *}(0.038) \\
{[0.117]}\end{array}$ & $\begin{array}{c}0.012(0.036) \\
{[0.098]}\end{array}$ & $\begin{array}{c}0.007(0.021) \\
{[0.037]}\end{array}$ & $\begin{array}{c}-0.065(0.047) \\
{[0.218]}\end{array}$ \\
\hline Urinary tract infection & $\begin{array}{c}-0.064 * *(0.030) \\
{[0.079]}\end{array}$ & $\begin{array}{c}-0.004(0.024) \\
{[0.047]}\end{array}$ & $\begin{array}{c}0.009(0.013) \\
{[0.014]}\end{array}$ & $\begin{array}{c}-0.054(0.036) \\
{[0.126]}\end{array}$ \\
\hline Allergic reactions & $\begin{array}{c}0.052(0.055) \\
{[0.380]}\end{array}$ & $\begin{array}{c}-0.022(0.048) \\
{[0.209]}\end{array}$ & $\begin{array}{c}-0.035(0.023) \\
{[0.047]}\end{array}$ & $\begin{array}{c}0.033(0.056) \\
{[0.485]}\end{array}$ \\
\hline Injury & $\begin{array}{c}-0.008(0.056) \\
{[0.475]}\end{array}$ & $\begin{array}{c}0.064(0.056) \\
{[0.388]}\end{array}$ & $\begin{array}{c}-0.020(0.032) \\
{[0.113]}\end{array}$ & $\begin{array}{c}0.024(0.052) \\
{[0.655]}\end{array}$ \\
\hline Burn & $\begin{array}{c}-0.047 * *(0.020) \\
{[0.024]}\end{array}$ & $\begin{array}{c}-0.015(0.011) \\
{[0.013]}\end{array}$ & $\begin{array}{c}0.006(0.006) \\
{[0]}\end{array}$ & $\begin{array}{c}-0.056 * *(0.022) \\
{[0.035]}\end{array}$ \\
\hline Anxiety & (no cases) & $\begin{array}{c}0.004(0.012) \\
{[0.013]}\end{array}$ & $\begin{array}{c}0.001(0.010) \\
{[0.006]}\end{array}$ & $\begin{array}{c}0.009(0.015) \\
{[0.018]}\end{array}$ \\
\hline Developmental delay & $\begin{array}{c}-0.034(0.048) \\
{[0.679]}\end{array}$ & $\begin{array}{c}-0.111 * *(0.053) \\
{[0.358]}\end{array}$ & $\begin{array}{c}-0.014(0.037) \\
{[0.141]}\end{array}$ & $\begin{array}{c}-0.040(0.046) \\
{[0.726]}\end{array}$ \\
\hline $\begin{array}{l}\text { Early } \\
\text { intervention/Special } \\
\text { education }\end{array}$ & $\begin{array}{c}-0.052(0.048) \\
{[0.659]}\end{array}$ & $\begin{array}{c}-0.099 *(0.053) \\
{[0.344]}\end{array}$ & $\begin{array}{c}-0.054(0.048) \\
{[0.242]}\end{array}$ & $\begin{array}{c}-0.061(0.046) \\
{[0.702]}\end{array}$ \\
\hline $\begin{array}{l}\text { Logged Medicaid costs } \\
(2009 \$)\end{array}$ & $\begin{array}{c}-0.238^{* *}(0.101) \\
{[\$ 120323]} \\
\end{array}$ & $\begin{array}{c}-0.284 *(0.152) \\
{[\$ 20952]}\end{array}$ & $\begin{array}{c}-0.304 *(0.178) \\
{[\$ 11366]} \\
\end{array}$ & $\begin{array}{c}-0.260 * * *(0.098) \\
{[\$ 152642]} \\
\end{array}$ \\
\hline
\end{tabular}

$\mathrm{N}=1,348$.

Robust standard errors are in parentheses. Control group means are in brackets. Each cell represents separate regression results. Regressions include the same covariates as in Table 2.

$*$, **, ***: significant at $<0.1,<0.05,<0.001$. 
Appendix Table 5. Treatment on the treated effects of SSI spells on diagnosis of new chronic conditions: Fuzzy regression discontinuity design (instrument: below the birthweight threshold)

\begin{tabular}{lcc}
\hline & $\begin{array}{c}\text { Earliest diagnosis of chronic } \\
\text { condition (age at months) before } \\
\text { age } 3\end{array}$ & $\begin{array}{c}\text { \# new chronic conditions at } \\
\text { Age } \in[0,3)\end{array}$ \\
\hline $\begin{array}{l}\text { \# months on SSI by age } 3 \\
\text { (months) }\end{array}$ & $0.308(0.339)$ & $-0.034^{*}(0.020)$ \\
Control group mean & 14.860 & 1.390
\end{tabular}

$\mathrm{N}=1,348$.

First stage coefficient $=6.038$, First stage F stat $=27.03$.

Robust standard errors are in parentheses. Each cell represents separate regression results. Regressions include the same covariates as in Table 2.

$*$, **, ***: significant at $<0.1,<0.05,<0.001$. 
Appendix Table 6. Effects of earlier health shocks on current healthcare utilization: Two-stage least squares regression.

\begin{tabular}{lcccc} 
& \multicolumn{3}{c}{ Healthcare utilization during age $\in$ [3, 6] } \\
\cline { 2 - 5 } & $\begin{array}{c}\text { Logged } \\
\text { Medicaid costs }\end{array}$ & $\begin{array}{c}\# \\
\text { hospitalization }\end{array}$ & $\begin{array}{c}\text { Length of } \\
\text { say, sum }\end{array}$ & $\begin{array}{c}\text { \# specialist } \\
\text { visits }\end{array}$ \\
\hline \# month on SSI by age 3 & -0.033 & -0.015 & $-0.179^{* *}$ & $-0.276^{*}$ \\
$\begin{array}{l}\text { (instrumented by an indicator for } \\
\text { below the cutoff) }\end{array}$ & $(0.024)$ & $(0.015)$ & $(0.084)$ & $(0.159)$ \\
Chronic conditions diagnosed by & $0.458^{* * *}$ & $0.099^{*}$ & 0.295 & $2.068^{* * *}$ \\
age 3 & $(0.079)$ & $(0.051)$ & $(0.301)$ & $(0.536)$ \\
\# month on SSI * Chronic & 0.002 & 0.003 & 0.019 & -0.015 \\
conditions diagnosed by age 3 & $(0.005)$ & $(0.003)$ & $(0.017)$ & $(0.034)$ \\
\hline
\end{tabular}

$\mathrm{N}=1,348$.

${ }^{\wedge}$ Value of 1 was assigned to those with zero cost.

Robust standard errors are in parentheses. Each cell represents separate regression results. Regressions include the same covariates as in Table 2. Chronic conditions include malnutrition, anemia, obesity, vision defect, hearing defect, asthma, genitourinary tract diseases, and developmental delay.

$*, * *, * * *$ : significant at $<0.1,<0.05,<0.001$. 
Appendix Table 7. Treatment on the treated effects of SSI spells on cumulative Medicaid costs: Fuzzy regression discontinuity design (instrument: below the birthweight threshold).

\begin{tabular}{lccc}
\hline & $\begin{array}{c}\text { First stage coefficient on SSI } \\
\text { spells }\end{array}$ & $\begin{array}{c}\text { Second stage coefficient on } \\
\text { cumulative Medicaid costs }\end{array}$ & $\begin{array}{c}\text { First stage F } \\
\text { statistics }\end{array}$ \\
\hline Age $\in[0,1)$ & $1.760^{* * *}(0.515)$ & $-0.118^{*}(0.070)$ & 11.55 \\
Age $\in[0,2)$ & $4.046^{* * *}(1.046)$ & $-0.057^{*}(0.030)$ & 27.97 \\
Age $\in[0,3)$ & $6.036^{* * *}(1.604)$ & $-0.038^{*}(0.020)$ & 27.01 \\
Age $\in[0,4)$ & $6.983^{* * *}(2.143)$ & $-0.034^{*}(0.019)$ & 28.87 \\
Age $\in[0,5)$ & $7.590^{* * *}(2.670)$ & $-0.032^{*}(0.018)$ & 36.41 \\
Age $\in[0,6)$ & $8.490^{* * *}(3.199)$ & $-0.029^{*}(0.017)$ & 46.92 \\
Age $\in[0,7)$ & $9.480^{* *}(3.730)$ & $-0.027^{*}(0.016)$ & 63.13 \\
Age $\in[0,8)$ & $10.487 * *(4.244)$ & $-0.024(0.015)$ & 72.37 \\
\hline
\end{tabular}

$\mathrm{N}=1,348$.

${ }^{\wedge}$ Value of 1 was assigned to those with zero cost.

Robust standard errors are in parentheses. Each cell represents separate regression results. Regressions include the same covariates as in Table 2.

$*$, **, ***: significant at $<0.1,<0.05,<0.001$. 
Appendix Table 8. Test of sample selection bias.

\begin{tabular}{|c|c|c|c|}
\hline & \multicolumn{3}{|c|}{$\begin{array}{c}\text { Outcome: Probability of continuous enrollment in } \\
\text { Medicaid }\end{array}$} \\
\hline & By age 3 & By age 6 & By age 8 \\
\hline Below the cutoff & $\begin{array}{l}-0.057 \\
(0.042)\end{array}$ & $\begin{array}{l}-0.017 \\
(0.044)\end{array}$ & $\begin{array}{l}-0.025 \\
(0.043)\end{array}$ \\
\hline $\begin{array}{l}\text { Below the cutoff * Neighborhood median } \\
\text { household income at birth }(\$ 1,000)\end{array}$ & $\begin{array}{c}0.001 \\
(0.0007)\end{array}$ & $\begin{array}{c}0.0007 \\
(0.0007)\end{array}$ & $\begin{array}{c}0.0009 \\
(0.0006)\end{array}$ \\
\hline
\end{tabular}

$\mathrm{N}=3,690$.

\# The 2009 American Community Survey (for places of birth in 2006-2010) 5-year estimates at census tract level. Study sample includes all infants whose birthweights $\in$ (900gram, 1,500gram), born in New York State in 20062010 , and born at 32 weeks of gestation or earlier.

$*$, **, $* * *$ : significant at $<0.1,<0.05,<0.001$. 
Appendix Table 9. Test of sample selection bias: Regression on cumulative outcomes by 3 varying by study sample.

\begin{tabular}{lccc}
\hline \multirow{2}{*}{ Outcome measures } & \multicolumn{2}{c}{ Sample: Continuously enrolled in Medicaid } \\
\cline { 2 - 4 } & By age 3 & By age 6 & $\begin{array}{c}\text { By age } 8 \text { (main } \\
\text { specification) }\end{array}$ \\
\hline SSI, ever & $0.175^{* * *}(0.040)$ & $0.157^{* * *}(0.047)$ & $0.153^{* * *}(0.052)$ \\
SSI, \# months & $6.636^{* * *}(1.190)$ & $6.374^{* * *}(1.408)$ & $6.076^{* * *}(1.572)$ \\
Malnutrition & $-0.026^{* * *}(0.010)$ & $-0.030^{* *}(0.013)$ & $-0.033^{* *}(0.013)$ \\
Upper respiratory tract infection & $-0.013(0.033)$ & $-0.055(0.038)$ & $-0.058(0.042)$ \\
Urinary tract infection & $-0.052^{* *}(0.023)$ & $-0.050^{*}(0.028)$ & $-0.064^{* *}(0.030)$ \\
Burn & $-0.026^{*}(0.014)$ & $-0.043^{* *}(0.017)$ & $-0.047^{* *}(0.020)$ \\
Mental problems & $-0.058^{*}(0.035)$ & $-0.069^{*}(0.040)$ & $-0.077^{*}(0.043)$ \\
Developmental delay & $-0.036(0.038)$ & $-0.041(0.044)$ & $-0.034(0.048)$ \\
Special education & $-0.032(0.039)$ & $-0.034(0.044)$ & $-0.052(0.048)$ \\
Logged Medicaid costs $(2009 \$)^{\wedge}$ & $-0.180^{* *}(0.082)$ & $-0.209^{* *}(0.093)$ & $-0.238^{* *}(0.101)$ \\
Hospitalization, ever & $-0.108^{* * *}(0.041)$ & $-0.106^{* *}(0.047)$ & $-0.106^{* *}(0.052)$ \\
\# specialist visits & $-3.111^{* * *}(0.964)$ & $-4.109^{* * *}(1.205)$ & $-4.837^{* * *}(1.417)$ \\
Observations & 2217 & 1637 & 1348 \\
\hline
\end{tabular}

${ }^{\wedge}$ Value of 1 was assigned to those with zero cost.

Robust standard errors are in parentheses. Each cell represents separate regression results. Regressions include the same covariates as in Table 2.

$*$, **, ***: significant at $<0.1,<0.05,<0.001$. 
Appendix Table 10. Robustness check: Association of the birthweight threshold with initial hospital stay at birth.

\begin{tabular}{lcc}
\hline & Logged Medicaid costs & Length of stay \\
\hline Below the cutoff & $0.013(0.081)$ & $-2.694(3.477)$ \\
Control group mean & $\$ 83585$ & 43.031
\end{tabular}

$\mathrm{N}=1,348$.

Robust standard errors are in parentheses. Each cell represents separate regression results. Regressions include the same covariates as in Table 2.

$*, * *, * * *$ : significant at $<0.1,<0.05,<0.001$. 
Appendix Table 11. Complier characteristics.

\begin{tabular}{|c|c|c|c|c|}
\hline & $\begin{array}{l}\text { Whole } \\
\text { sample }\end{array}$ & Complier & $\begin{array}{l}\text { Never- } \\
\text { takers }\end{array}$ & $\begin{array}{c}\text { Always- } \\
\text { takers }\end{array}$ \\
\hline Female & 0.467 & 0.392 & 0.446 & 0.625 \\
\hline Non-Hispanic White & 0.335 & 0.220 & 0.280 & 0.500 \\
\hline Non-Hispanic Black & 0.220 & 0.278 & 0.245 & 0.125 \\
\hline Hispanic & 0.309 & 0.332 & 0.313 & 0.250 \\
\hline New York City resident & 0.507 & 0.532 & 0.527 & 0.500 \\
\hline Low neighborhood poverty rate (Q1) & 0.197 & 0.281 & 0.212 & 0 \\
\hline High neighborhood poverty rate (Q4) \# & 0.270 & 0.185 & 0.226 & 0.375 \\
\hline Low neighborhood median household income (Q1) & 0.304 & 0.224 & 0.253 & 0.375 \\
\hline High neighborhood median household income (Q4) & 0.211 & 0.294 & 0.259 & 0.125 \\
\hline Low neighborhood high school graduate rate (Q1) & 0.292 & 0.218 & 0.250 & 0.375 \\
\hline High neighborhood high school graduate rate (Q4) & 0.244 & 0.246 & 0.286 & 0.375 \\
\hline
\end{tabular}

$\mathrm{N}=1,348$.

\# Based on the 2009 American Community Survey estimates at the census tract level.

The above values represent kappa-weighted means from Abadie's (2003) theorem: $E\left[x \mid D_{1}>D_{0}\right]=$ $\frac{E\left[D_{i} \mid Z_{i}=1, x=1\right]-E\left[D_{i} \mid Z_{i}=0, x=1\right]}{E\left[D_{i} \mid Z_{i}=1\right]-E\left[D_{i} \mid Z_{i}=0\right]}$ where $D$ is treatment assignment, $Z$ is instrument (total number of SSI benefits until age 4), and $x$ is covariates. The total number of months on SSI is used as an instrument for the analysis. 